\title{
Reminders, payment method and charitable giving: evidence from an online experiment
}

\author{
By Axel Sonntag and Daniel John Zizzo \\ School of Economics and CBESS, University of East \\ Anglia.
}

\begin{abstract}
We present the results of an experiment testing whether different methods of payment in combination with different reminder intervals affect the amounts of charitable donations. Following a lab session, participants could make online donations to charity for a total duration of three months. Reminder intervals and payment methods did not affect the total amounts donated, although participants were more likely to donate at least once when receiving monthly (and not weekly) email reminders.
\end{abstract}

JEL classification codes

C91, D64, L31

Keywords

charitable giving, payment method, reminders, online experiment

Centre for Behavioural and Experimental Social Science University of East Anglia Norwich Research Park Norwich NR4 7TJ United Kingdom www.uea.ac.uk/ssf/cbess 


\title{
Reminders, payment method and charitable giving: evidence from an online experiment
}

\author{
Axel Sonntag \& Daniel John Zizzo \\ CBESS and School of Economics, University of East Anglia \\ a.sonntag@uea.ac.uk \& d.zizzo@uea.ac.uk.
}

\begin{abstract}
We present the results of an experiment testing whether different methods of payment in combination with different reminder intervals affect the amounts of charitable donations. Following a lab session, participants could make online donations to charity for a total duration of three months. Reminder intervals and payment methods did not affect the total amounts donated, although participants were more likely to donate at least once when receiving monthly (and not weekly) email reminders.
\end{abstract}

Keywords: charitable giving, payment method, reminders, online experiment

JEL Classification: C91, D64, L31 


\section{Introduction}

"Out of sight, out of mind” applies to many occasions in daily life. Both casual and research evidence point towards the fact that people are likely to pay more attention to things they are reminded of. Conversely, products or tasks that people are not reminded of, especially when other products or tasks are heavily advertised, are likely to lose out with respect to attracting people's attention. Standing orders may be a way of getting around the problem.

This paper looks at whether donations to charity can be increased by reminding people of their opportunity to donate to charity and by allowing for standing orders as opposed to oneoff donations. Simple and cheap 'nudge' interventions of this kind are very much in policy demand, though not without qualifications (Loewenstein et al., 2012). Reminders have been tested in other settings, ${ }^{1}$ and an empirical paper looking at 1990 Family Expenditure Survey data suggests that standing orders may again be helpful (Jones and Marriott 1994). We also look at the effect of varying time intervals of reminders, which other papers have not considered. We think this is relevant because it is not clear whether reminding people very frequently increased attention levels or, conversely, might even put people off, because they might feel being 'spammed'.

\section{Research Design}

The opportunity of donating to charity is typically very salient when offered in a lab context. In daily life however making donations to charitable organizations is only one out of many things one can do in and potentially one which is even deemed to have lower priority than many other tasks. That is why, instead of a pure lab experiment, we used a combination of a standard lab and an online experiment. We implemented a 3 (reminder frequency: no reminder, monthly or weekly reminders) x 2 (method of donation: standing order or one-off donation) factorial design (see Table 1).

\section{[Table 1 here]}

Only participants who answered a pre-lab online questionnaire were admitted to the lab session. In a real effort task participants counted " $1 \mathrm{~s}$ ” in a $5 \times 5$ matrix and each participant could earn a lump sum of $£ 15$, if he/she answered the correct number of " $1 \mathrm{~s}$ " of at least 15

\footnotetext{
${ }^{1}$ Huck and Rasul (2010, 2008), Poortinga et al. (2003) and Tepper (1994) used reminders as a tool to increase response rates; Calzolari and Nardotto (2011) and Carroll et al. (2005) reminded people to take decisions or actions that otherwise would not have been taken at all.
} 
matrices within ten minutes. ${ }^{2}$ However, we made clear beforehand that if they exceeded the threshold they would not be paid directly after the session but would receive a monthly salary of $£ 5$ per month for the duration of three months, paid to their personal experimental account. Participants were informed about the specific payment dates, trained how to logon the online experimental portal and how to check their account balances online. Furthermore, they learned that they could use their salaries to make donations to Oxfam. ${ }^{3}$ After checking whether participants really understood the experimental set up, participants were paid a participation fee of $£ 2$ and left the lab.

During the following three months, depending on their treatment, participants received no, monthly or weekly emails in which we reminded them on their opportunity to check their account balance and to donate to charity by logging on to the online experimental portal. ${ }^{4}$ After three months, participants filled a final questionnaire stating their motives for them not donating (if applicable), and collected their final payment; donated amounts were passed on to Oxfam as promised.

\section{Results}

Table 2 contains some descriptive statistics; donations in our experiment were comparatively low (only about $5 \%$ of the endowment). ${ }^{5}$

[Table 2 here]

Result 1: While participants donated slightly more the higher the frequency with which reminders were sent was, this is not statistically significant. ${ }^{6}$

Result 2: While the average donation per participant in the standing order treatments was slightly larger than with one-off donations, the difference is not statistically significant. ${ }^{7}$

The results above were confirmed by a regression analysis (see Table 3). The coefficients of the main treatment variables and their interactions were statistically insignificant. Participants

\footnotetext{
${ }^{2}$ We opted for a real effort task because Carlsson et al., (2012) and Reinstein and Riener (2009) found evidence of house money effects in experiments on charitable giving.

${ }^{3}$ At this time, participants had the opportunity to browse the website of Oxfam for as long as they wished.

${ }^{4}$ The texts of the reminder emails and all instructions can be found in the online appendix.

${ }^{5}$ Donations were $5.63 \%$ of consumer expenditure according to a recent US consumer expenditure survey (BLS, 2012).

${ }^{6}$ Wilcoxon tests: no reminder vs. monthly: $\mathrm{p}=0.381$; no reminder vs. weekly: $\mathrm{p}=0.258$; monthly vs. weekly: $\mathrm{p}=0.817$. All tests in this paper are two-sided.

${ }^{7}$ Wilcoxon test: $\mathrm{p}=0.481$.
} 
who stated that they were short on money and needed to take care of their own finances first before donating to charity ('selfish motive'), that they were already donating to another charity or that they would not be willing to donate to Oxfam in particular, had donated much less than their co-participants (see columns 2 and 3 of Table 3).

[Table 3 here]

Although nonparametric tests do not indicate significant differences, when controlling for personal characteristics, participants were more likely to make at least one donation in treatments with higher reminder frequencies (see columns 5 and 6 of Table 3). ${ }^{8}$ There is also marginal evidence $(p<0.1)$ from the regression analysis that, when controlling for covariates, the average number of donations slightly increased with monthly reminders (see column 9 of Table 3). ${ }^{9}$

We conducted a power analysis to check whether increasing the sample size would have resulted in higher significance levels for the total amount donated. ${ }^{10}$ Given our observed data, we would have needed on average over 2300 subjects per treatment in order to find statistically significant differences between the treatments. Thus, our main finding of nonsignificance seemed to be reasonably robust against increasing the sample size.

\section{Discussion and conclusion}

We did not find a statistically significant effect of reminders and having standing orders. While this is not good news for charities, as the 'nudge' policy agenda comes into empirical scrutiny, we believe that documenting its failures is as important as documenting its successes. ${ }^{11}$ We did find some evidence that monthly reminders but not weekly reminders are effective in inducing at least one donation. Weekly reminders may not be more effective than monthly reminders because they might be seen as resembling spamming and therefore be more easily ignored.

\footnotetext{
${ }^{8}$ Wilcoxon tests: no reminder vs. monthly: $\mathrm{p}=0.326$; no reminder vs. weekly: $\mathrm{p}=0.244$; monthly vs. weekly: $\mathrm{p}=0.857$.

${ }^{9}$ This is not picked up by nonparametric tests: Wilcoxon tests: no reminder vs. monthly: $\mathrm{p}=0.279$; no reminder vs. weekly: $\mathrm{p}=0.215$; monthly vs. weekly: $\mathrm{p}=0.875$.

${ }^{10}$ We used the software G*Power 3.1 (Faul et al., 2009).

${ }^{11}$ Carroll et al. (2009) and Karlan et al. (2010) did not find an effect of simple reminders alone in the contexts of choosing pension schemes and saving regularly, respectively. Calzolari and Nardotto (2011) in their fitness center context found no reminder effect for 'high attenders'.
} 
We conjecture that two things might have led to a lower effectiveness of our 'nudge' interventions than we expected. First, three months are still a finite horizon that terminates any standing orders in the foreseeable future. Thus participants might, quite rationally, have decided on the amount they wanted to donate and then, dependent on their method of payment, either donated this amount in a one-off transaction or set up a standing order that transfers one third of the planned amount each month. Second, in the questionnaire before receiving their final payment, many participants mentioned that they were living on a tight budget and they needed to keep track of their financial activities very precisely rather than donating money to a charity. ${ }^{12}$ Suffering from financial pressure might draw more attention to financial issues in general which could make it less likely to fall for a status quo bias in financial matters or to 'forget' about an initially set up standing order. Clearly, further research is needed.

\section{Acknowledgements}

The financial support of the ESRC (NIBS Grant ES/K002201/1) is gratefully acknowledged. We thank Ailko van der Veen for excellent research assistance; the usual disclaimer applies. The experimental data and instructions are available as online appendices.

\section{References}

BLS, 2012. Consumer expenditure survey. US Bureau of Labor Statistics.

Calzolari, G., Nardotto, M., 2011. Nudging with information: a randomized field experiment on reminders and feedback. Cent. Econ. Policy Res. - Discuss. Pap. 8571.

Carlsson, F., He, H., Martinsson, P., 2012. Easy come, easy go. Exp. Econ. 16, 190-207.

Carroll, G.D., Choi, J.J., Laibson, D., Madrian, B.C., Metrick, A., 2009. Optimal defaults and active decisions. Q. J. Econ. 124, 1639-1674.

Faul, F., Erdfelder, E., Buchner, A., Lang, A.-G., 2009. Statistical power analyses using G*Power 3.1: tests for correlation and regression analyses. Behav. Res. Methods 41, 1149-60.

Huck, S., Rasul, I., 2008. Comparing charitable fundraising schemes: evidence from a natural field experiment. Unpubl. Work. Pap.

\footnotetext{
${ }^{12}$ This is plausible given that we employed university students as our sample, and fits with the negative 'Selfish motives', 'Already donating' and 'No money for Oxfam' coefficients in columns 2 and 3 of Table 3.
} 
Huck, S., Rasul, I., 2010. Transactions costs in charitable giving: evidence from two field experiments. B.E. J. Econ. Anal. Policy - Adv. 10.

Jones, A., Marriott, R., 1994. Determinants of the level and methods of charitable giving in the 1990 Family Expenditure Survey. Appl. Econ. Lett. 1, 200-203.

Karlan, D., McConnell, M., Mullainathan, S., Zinman, J., 2010. Getting to the Top of Mind: How Reminders Increase Saving. NBER Work. Paper 16205.

Loewenstein, G., Asch, D.A., Friedman, J.Y., Melichar, L.A., 2012. Can behavioural economics make us healthier? Br. Med. J. 344, 1-3.

Poortinga, W., Steg, L., Vlek, C., Wiersma, G., 2003. Household preferences for energysaving measures: A conjoint analysis. J. Econ. Psychol. 24, 49-64.

Reinstein, D., Riener, G., 2009. House Money Effects on Charitable Giving: An Experiment. Unpubl. Work. Pap.

Tepper, K., 1994. The Role of Labeling Processes in Elderly Consumers' Responses to Age Segmentation Cues. J. Consum. Res. 20, 503-519.

Table 1: Experimental design and numbers of subjects per treatment

\begin{tabular}{lccc}
\hline & No reminder & Monthly reminders & Weekly reminders \\
\hline Standing order & 39 & 38 & 39 \\
One-off donation & 39 & 39 & 39 \\
\hline
\end{tabular}

Table 2: Descriptive Statistics

\begin{tabular}{lcccccccc}
\hline Method of donation & \multicolumn{3}{c}{ One-off donation } & \multicolumn{5}{c}{ Standing order } \\
Reminder intensity & once & monthly & weekly & once & monthly & weekly & overall \\
\hline \multirow{2}{*}{ Amount donated out of $£ 15$} & 0.615 & 0.641 & 0.590 & 0.513 & 0.579 & 1.538 & 0.747 \\
& $(0.407)$ & $(0.393)$ & $(0.404)$ & $(0.254)$ & $(0.255)$ & $(0.658)$ & $(0.171)$ \\
Probability of making any donation & 0.103 & 0.179 & 0.103 & 0.103 & 0.132 & 0.231 & 0.142 \\
& $(0.049)$ & $(0.062)$ & $(0.049)$ & $(0.049)$ & $(0.056)$ & $(0.068)$ & $(0.023)$ \\
\multirow{2}{*}{ Number of submissions } & 0.282 & 0.513 & 0.385 & 0.359 & 0.553 & 0.795 & 0.481 \\
& $(0.122)$ & $(0.160)$ & $(0.120)$ & $(0.125)$ & $(0.206)$ & $(0.258)$ & $(0.07)$ \\
\hline
\end{tabular}


Table 3: Regression Analysis

\begin{tabular}{|c|c|c|c|c|c|c|c|c|c|}
\hline & (1) & (2) & (3) & (4) & (5) & (6) & (7) & (8) & (9) \\
\hline Standing order & $\begin{array}{l}-0.278 \\
(3.854)\end{array}$ & $\begin{array}{l}-0.457 \\
(3.652)\end{array}$ & $\begin{array}{l}-0.118 \\
(3.626)\end{array}$ & $\begin{array}{c}0.000 \\
(0.384)\end{array}$ & $\begin{array}{l}-0.112 \\
(0.423)\end{array}$ & $\begin{array}{l}-0.070 \\
(0.448)\end{array}$ & $\begin{array}{c}0.269 \\
(0.315)\end{array}$ & $\begin{array}{c}0.210 \\
(0.325)\end{array}$ & $\begin{array}{c}0.172 \\
(0.340)\end{array}$ \\
\hline Monthly reminders & $\begin{array}{c}2.577 \\
(3.630)\end{array}$ & $\begin{array}{c}4.255 \\
(3.386)\end{array}$ & $\begin{array}{c}5.063 \\
(3.421)\end{array}$ & $\begin{array}{c}0.350 \\
(0.359)\end{array}$ & $\begin{array}{c}0.583 \\
(0.387)\end{array}$ & $\begin{array}{l}0.711^{*} \\
(0.413)\end{array}$ & $\begin{array}{c}0.407 \\
(0.310)\end{array}$ & $\begin{array}{c}0.518 \\
(0.315)\end{array}$ & $\begin{array}{l}0.611^{*} \\
(0.331)\end{array}$ \\
\hline Weekly reminders & $\begin{array}{l}-0.069 \\
(3.840)\end{array}$ & $\begin{array}{l}-0.023 \\
(3.593)\end{array}$ & $\begin{array}{c}1.157 \\
(3.653)\end{array}$ & $\begin{array}{c}0.000 \\
(0.384)\end{array}$ & $\begin{array}{c}0.006 \\
(0.420)\end{array}$ & $\begin{array}{c}0.152 \\
(0.452)\end{array}$ & $\begin{array}{c}0.293 \\
(0.314)\end{array}$ & $\begin{array}{c}0.301 \\
(0.322)\end{array}$ & $\begin{array}{c}0.316 \\
(0.340)\end{array}$ \\
\hline $\begin{array}{l}\text { Standing order } \mathrm{x} \\
\text { monthly reminders }\end{array}$ & $\begin{array}{l}-1.317 \\
(5.224)\end{array}$ & $\begin{array}{l}-2.538 \\
(4.863)\end{array}$ & $\begin{array}{l}-3.822 \\
(4.892)\end{array}$ & $\begin{array}{l}-0.202 \\
(0.518)\end{array}$ & $\begin{array}{l}-0.289 \\
(0.564)\end{array}$ & $\begin{array}{l}-0.427 \\
(0.597)\end{array}$ & $\begin{array}{l}-0.284 \\
(0.428)\end{array}$ & $\begin{array}{l}-0.296 \\
(0.436)\end{array}$ & $\begin{array}{l}-0.177 \\
(0.461)\end{array}$ \\
\hline $\begin{array}{l}\text { Standing order x } \\
\text { weekly reminders }\end{array}$ & $\begin{array}{c}5.792 \\
(5.235)\end{array}$ & $\begin{array}{l}7.527 \\
(5.023)\end{array}$ & $\begin{array}{c}6.392 \\
(5.046)\end{array}$ & $\begin{array}{c}0.531 \\
(0.520)\end{array}$ & $\begin{array}{c}0.928 \\
(0.581)\end{array}$ & $\begin{array}{c}0.881 \\
(0.622)\end{array}$ & $\begin{array}{c}0.027 \\
(0.426)\end{array}$ & $\begin{array}{c}0.216 \\
(0.442)\end{array}$ & $\begin{array}{c}0.380 \\
(0.471)\end{array}$ \\
\hline Payment not collected & & $\begin{array}{c}0.298 \\
(2.576)\end{array}$ & $\begin{array}{l}-0.658 \\
(2.695)\end{array}$ & & $\begin{array}{l}-0.413 \\
(0.311)\end{array}$ & $\begin{array}{l}-0.555 \\
(0.347)\end{array}$ & & $\begin{array}{l}-0.436 \\
(0.275)\end{array}$ & $\begin{array}{l}-0.379 \\
(0.292)\end{array}$ \\
\hline 'Forgot to donate' & & $\begin{array}{l}-1.680 \\
(2.718)\end{array}$ & $\begin{array}{l}-2.477 \\
(2.725)\end{array}$ & & $\begin{array}{l}-0.184 \\
(0.312)\end{array}$ & $\begin{array}{l}-0.247 \\
(0.332)\end{array}$ & & $\begin{array}{l}-0.155 \\
(0.264)\end{array}$ & $\begin{array}{l}-0.060 \\
(0.275)\end{array}$ \\
\hline 'Selfish motives' & & $\begin{array}{c}-12.88^{* * *} \\
(4.644)\end{array}$ & $\begin{array}{c}-14.57 * * * \\
(5.030)\end{array}$ & & $\begin{array}{c}-1.523 * * * \\
(0.482)\end{array}$ & $\begin{array}{c}-1.812^{* * *} \\
(0.542)\end{array}$ & & $\begin{array}{c}-0.644^{* *} \\
(0.267)\end{array}$ & $\begin{array}{r}-0.634 * * \\
(0.294)\end{array}$ \\
\hline 'Already donating' & & $\begin{array}{c}-11.88^{* *} \\
(4.916)\end{array}$ & $\begin{array}{c}-14.44 * * * \\
(5.211)\end{array}$ & & $\begin{array}{c}-1.410 * * * \\
(0.524)\end{array}$ & $\begin{array}{c}-1.833^{* * *} \\
(0.585)\end{array}$ & & $\begin{array}{c}-1.090 * * * \\
(0.389)\end{array}$ & $\begin{array}{c}-0.906 * * \\
(0.415)\end{array}$ \\
\hline 'No money for Oxfam' & & $\begin{array}{c}-9.98^{* * * *} \\
(3.806)\end{array}$ & $\begin{array}{c}-9.61 * * * \\
(3.725)\end{array}$ & & $\begin{array}{c}-1.225 * * * \\
(0.405)\end{array}$ & $\begin{array}{c}-1.260^{* * *} \\
(0.426)\end{array}$ & & $\begin{array}{l}-0.325 \\
(0.252)\end{array}$ & $\begin{array}{l}-0.414 \\
(0.263)\end{array}$ \\
\hline 'Organised person' & & & $\begin{array}{c}0.036 \\
(0.706)\end{array}$ & & & $\begin{array}{l}-0.001 \\
(0.015)\end{array}$ & & & $\begin{array}{c}0.077 \\
(0.067)\end{array}$ \\
\hline 'Busy person' & & & $\begin{array}{c}0.440 \\
(0.821)\end{array}$ & & & $\begin{array}{l}-0.073^{*} \\
(0.044)\end{array}$ & & & $\begin{array}{c}-0.139 * * \\
(0.071)\end{array}$ \\
\hline Mails per day & & & $\begin{array}{c}0.071 \\
(0.068)\end{array}$ & & & $\begin{array}{c}0.007 \\
(0.086)\end{array}$ & & & $\begin{array}{l}-0.001 \\
(0.008)\end{array}$ \\
\hline Intercept & $\begin{array}{c}-12.79 * * * \\
(3.450)\end{array}$ & $\begin{array}{c}-8.068^{* *} \\
(3.204)\end{array}$ & $\begin{array}{c}-5.896 \\
(10.846)\end{array}$ & $\begin{array}{c}-1.267 * * * \\
(0.272)\end{array}$ & $\begin{array}{c}-0.805^{* *} \\
(0.332)\end{array}$ & $\begin{array}{l}-1.285 \\
(1.362)\end{array}$ & & & \\
\hline Demographics & no & no & yes & no & no & yes & no & no & yes \\
\hline Psychological inventories & no & no & yes & no & no & yes & no & no & yes \\
\hline AIC & 375.522 & 357.371 & 369.892 & 197.816 & 180.608 & 194.272 & 422.379 & 419.401 & 421.939 \\
\hline BIC & 399.68 & 398.784 & 445.815 & 218.522 & 218.569 & 266.744 & 456.89 & 471.167 & 508.214 \\
\hline Log Likelihood & -180.761 & -166.686 & -162.946 & -92.908 & -79.304 & -76.136 & -201.19 & -194.701 & -185.969 \\
\hline Deviance & 146.73 & 128.017 & 123.936 & 185.816 & 158.608 & 152.272 & 402.379 & 389.401 & 371.939 \\
\hline Right-censored & 0 & 0 & 0 & & & & & & \\
\hline Left-censored & 200 & 200 & 200 & & & & & & \\
\hline Uncensored & 33 & 33 & 33 & & & & & & \\
\hline
\end{tabular}

n: 233; Columns 1, 2 and 3: Tobit regressions on the total amount donated per participant; columns 4, 5 and 6: Probit regressions on the likelihood of making any donation at all (explained variable $=1$ if at least one donation was made, 0 otherwise); columns 7, 8 and 9: Ordered probit regressions on the number of donations made. We categorized the qualitative answers which were recorded before the final payment was made. The variables in single quotes are encoded dummies that are mutually exclusively 1 if the main reason for not-donating matches the dummy's name and 0 otherwise. Other reasons were summarized as 'other reasons' and defined the base-category for this dummy specification. 'Mails per day' refers to the number of emails that subjects stated they received each day. Significance: ${ }^{* * *} \mathrm{p}<0.01,{ }^{* *} \mathrm{p}<0.05,{ }^{*} \mathrm{p}<0.1$. 